\title{
Sacroiliac Joint Intraarticular Injection in True Anteroposterior View: Description of a New C-Arm Guided Method
}

Arman Taheri, MD1', Mahbod Lajevardi, MD², Mohsen Abad, MD ${ }^{1,3}$, Jayran Zebardast, RN ${ }^{1}$, and Sanaz Shaabani, MD ${ }^{1,4}$

From: ${ }^{1}$ Brain and Spinal Cord Injury Research Center, Neuroscience Institute, Tehran University of Medical Sciences, Tehran, Iran; ${ }^{2}$ Department of Anesthesiology and Critical Care and Pain Medicine, Sina Hospital, Tehran University of Medical Sciences, Tehran, Iran; ${ }^{3}$ North Khorasan University of Medical Sciences, Bojnurd, Iran; 4Department of Anesthesiology and Critical care and Pain Medicine, Shahid Modarres Hospital, Saveh University of Medical Sciences, Saveh, Iran

Address Correspondence: Sanaz Shaabani, MD Imam Khomeini Hospital Department of Anesthesiology and Critical Care, and Pain Medicine

Tehran University of Medical Sciences, Tehran, Iran E-mail: Sanazshaabani@yahoo.com

Disclaimer: There was no external funding in the preparation of this manuscript. Conflict of interest: Each author certifies that he or she, or a member of his or her immediate family, has no commercial association (i.e., consultancies, stock ownership, equity interest, patent/licensing arrangements, etc.) that might pose a conflict of interest in connection with the submitted manuscript.

Manuscript received: 04-07-2017 Revised manuscript received: 07-31-2017 Accepted for publication: 08-08-2017

Free full manuscript: www.painphysicianjournal.com
Background: The anatomic characteristics of the sacroiliac joint (SIJ) make it difficult to achieve intraarticular injection without radiologic guidance. The classic C-arm guided SIJ intervention technique is difficult. Here we describe a new and simple method for SIJ intraarticular intervention

Objective: This study aims to introduce a new, simple approach for SIJ intraarticular intervention.

Study Design: An observational case series study.

Setting: The study was conducted at an academic medical center in a major metropolitan city.

Methods: This method of intervention was performed on 57 patients (a total of 73 joints) who were selected for diagnostic and therapeutic SIJ intervention. The procedure was done in anteroposterior (AP) view, without any C-arm angulation. The accuracy of the intraarticular injection was confirmed by using intraarticular contrast material. A numerical rating scale (NRS) score was recorded for each joint before and after the procedure; the number of $x$-ray exposures and number of attempts were recorded for each procedure as well.

Results: Successful intraarticular contrast spread was obtained in all SIJs. The number of $x$-ray exposures was about $9 \pm 3$, and there was not a remarkable difference between cases according to gender of the patient $(P=0.1)$ or side of the joint $(P=0.2)$. In 5 cases, the first needle placement was not correct; there were no differences between gender $(P=0.4)$ and side of the joint $(P=0.4)$ regarding the first successful attempt. The NRS pain scores decreased in all of the patients more than $50 \%$ after the procedure; the pain scores were similar to the results of classic methods of intraarticular interventions with successful contrast spread, and there were no remarkable differences considering gender $(P=0.5)$ or side of the joint $(P=0.8)$.

Limitations: This is a very small, nonrandomized, and controlled study; further blinded clinical trials are needed to clarify the probable advantages of this method compared with conventional ones.

Conclusion: This observational study introduces a new and simple approach for SIJ intraarticular intervention, with a high success rate.

Key words: Low back pain, sacroiliac joint, C-arm, new technique, intraarticular, injection

Pain Physician 2018; 21:61-66 acroiliac joint (SIJ) dysfunction is an important cause of chronic low back pain $(1,2)$, and the most reliable method to verify this condition is diagnostic intraarticular local anesthetic injection (2).
SIJ intervention is a common procedure performed by pain specialists, and there are different methods for SIJ intraarticular injections $(3,4)$. The anatomic characteristics of the SIJ make it difficult to achieve 
intraarticular injection without radiologic guidance; furthermore, other methods report lower rates of successful intraarticular drug delivery (5). It is difficult to achieve intraarticular injection in the classic C-arm guided SIJ intervention technique, and when the needle is not in the correct position by injecting even a low volume of contrast material, the ideal image of the articular lines will be lost and further needle replacement will be more difficult $(6,7)$. In recent years, modified useful techniques for SIJ intervention are reported in the literature, but none of them perform the procedure in anteroposterior (AP) view without any $\mathrm{C}$-arm angulation. Here we describe a new method for SIJ intraarticular intervention that achieves intraarticular injection with few x-ray exposures and a high successful rate.

\section{Methods}

This method of intervention was performed from January 2016 to September 2016 on 57 patients who were selected for diagnostic and therapeutic SIJ intervention. The patients included were 25-65 years old, with a chief complaint of chronic low back pain and at least 3 positive SIJ tests that included positive Gaenslen and FABER tests. The method of procedure, the reason why the procedure should be performed, and the benefits and side effects of the procedure were completely described for each patient; after clarifying the matter,

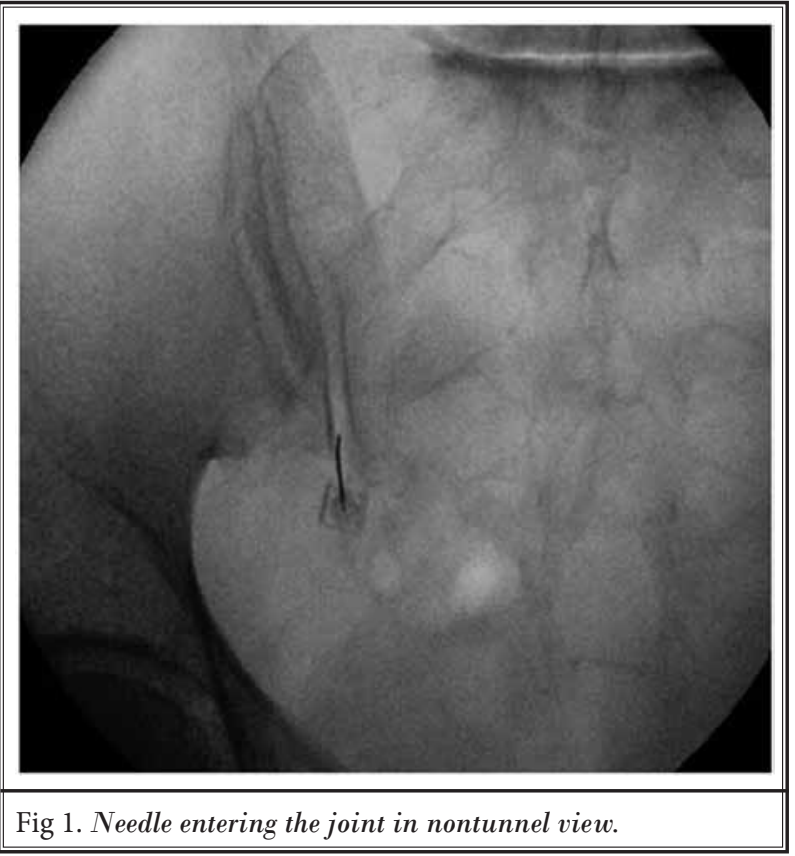

written consent inform was obtained. Patients with any comorbidity, such as diabetes and cardiovascular disease, were not enrolled in this study. Also, important general contraindications for pain procedures such as local or systemic infection, psychological disease, allergy to local anesthetics, and coagulopathy were considered as exclusion criteria. Among the 57 patients included in the study, 16 patients had bilateral SIJ intervention and a total of 73 SIJs were injected.

The pain intensity measurement was done by using a numerical rating scale (NRS). The score was recorded before and after the procedure on the same day. The accuracy of the intraarticular injection was confirmed by using intraarticular contrast material. The number of $\mathrm{x}$-ray exposures for each intervention was also recorded.

After obtaining intravenous access and vital sign monitoring, the patients were positioned prone on the procedure table, and by placing a pillow beneath the iliac crest, we flattened the lumbar lordosis. The site of intervention was prepared and draped using sterile techniques. An AP view of the joint was visualized as first image without any C-arm angulation; the posterior and anterior articular lines were visualized as medial and lateral divergent silhouettes, respectively. A few millimeters below the medial silhouette was marked as the entry site. This site was locally anesthetized, and then we placed a 22-gauge, curved-tip sharp spinal needle in tunnel view and advanced it in a nontunnel pathway into the lower part of the medial silhouette by image guidance (Fig. 1). The tip of the needle remained targeted exactly on the lucent area between 2 cortical lines of the posterior articular surface, which is visualized as medial silhouettes, until it penetrated the joint capsule and the operator felt the difference of tissue resistance. Once the needle hit the bone on the entrance to the joint, it was redirected to the joint space by slight image-guided angulation. After proper needle positioning, 2 3-degree ipsilateral and contralateral oblique images were visualized to confirm that the tip of the needle was in the lucent area of the joint space (Fig. 2). Next, $0.2 \mathrm{~mL}$ of contrast material was injected to confirm the intraarticular needle position (Fig. 3). By injecting the contrast, 2 distinct divergent lines of the articular surfaces appeared in medial and lateral. The combination of local anesthetic and corticosteroid was then injected, and the dilution of the contrast was visualized in second image. The NRS score for each joint was recorded before and after the intervention, and the percentage of pain relief was calculated according to each paired NRS difference. The number of x-ray expo- 


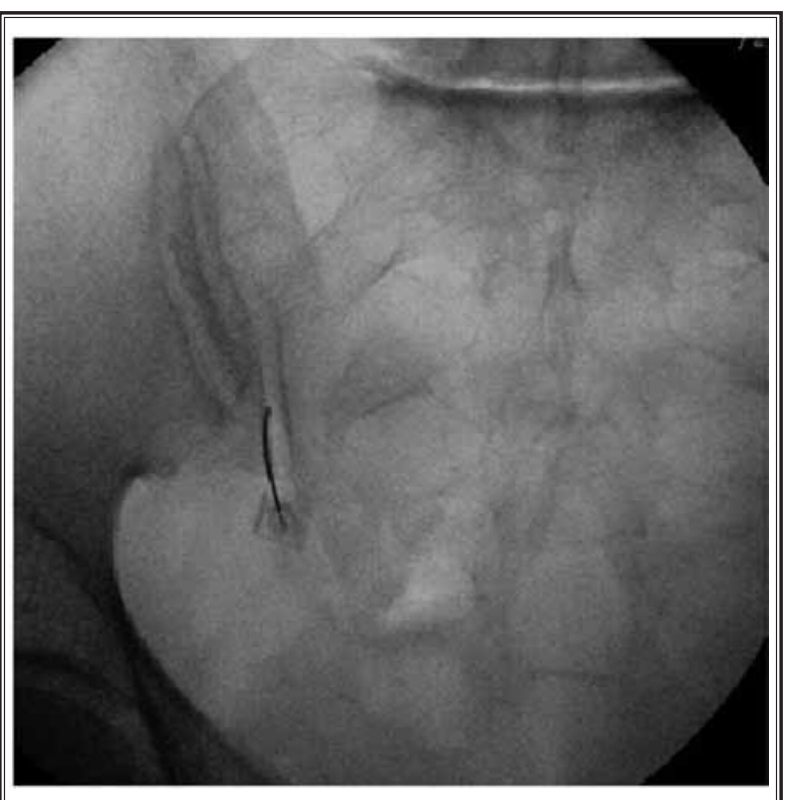

Fig 2. Needle in the joint and C-arm angulation 3-degree to right that certifies that the tip of the needle was in lucent area of joint space.

sures and number of attempts for intraarticular needle placement were recorded during each procedure also.

\section{Results}

Thirty-one men and 26 women were enrolled in this study, with an age range of 25-65 years old. A total of 73 joints were injected, 38 right SIJs and 35 left SIJs. Both the intraarticular contrast and drug spread were satisfactory in all of the cases.

The gender and age of each patient, side of the joint, NRS score for each joint before and after the procedure, percentage of pain relief, number of attempts, and number of x-ray exposures are presented in Table 1.

\section{Discussion}

The SIJ is the largest diarthrodial joint of the body, with fibrocartilage and hyaline cartilage structure $(8,9)$. This large joint is stabilized by a number of muscular and ligamentous attachments $(8,10)$. The SIJ is innervated by lower lumbar L4, L5, and sacral dorsal rami that transmit pain and proprioception from the joint $(8,11)$. There are variations in shape, structure, and innervation of SIJs in adults $(8,12)$ that make it difficult to perform intraarticular interventions without radiologic or ultrasonography guidance $(3,12,13)$. The blind method, even when done by an experienced hand, has low rates of success (14). According to previous studies,

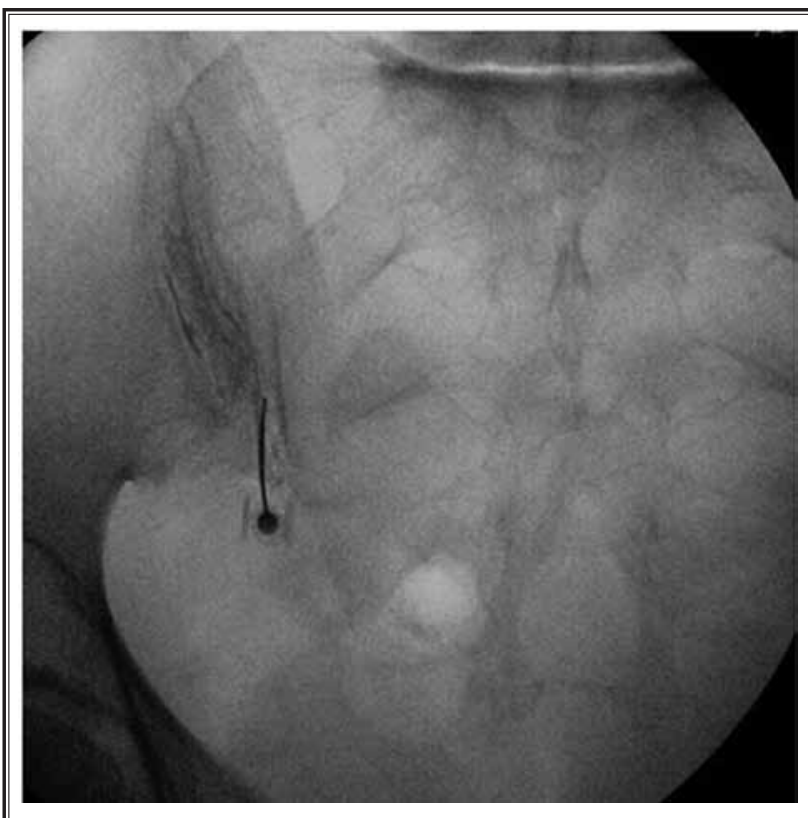

Fig 3. Final image with contrast material in SIJ.

using radiographic guidance will yield better results (13). In true AP view of the joint, 2 distinct divergent articular lines are visualized, each containing a hyper lucent area between their cortical silhouettes, which is the joint space. In this view in most people, the medial articular line is a posterior articular structure and the lateral line is an anterior articular structure $(8,12,15)$.

In the classic C-arm guided SIJ injection technique while the patient is lying prone, the C-arm is rotated contralateral until the posterior and anterior articulation lines of the joint, which are viewed respectively as medial and lateral silhouette lines, will be superimposed and the most lucent area between 2 cortical lines will be appeared as the joint space; by tilting the C-arm caudally, the posterior superior iliac spine will uncover the inferior articular lines of the SIJ $(4,12,14)$. There are also modified techniques that recommend performing the procedure without completely superimposing the articular lines $(4,12)$. The double needle method is recommended under dynamic fluoroscopy guidance to increase the chance of intraarticular needle placement (16), and lateral view is suggested to verify correct intraarticular needle placement (12). There is no previous scientific report of entering the joint in true AP view without any C-arm angulation. Accidentally, we noticed that by using true AP view we can identify the posterior articular surface easier. In this method, the needle entry into the inferior part of the joint will be 
Pain Physician: January/February 2018; 21:61-66

Table 1. Demographic data and procedural characteristics.

\begin{tabular}{|c|c|c|c|c|c|c|c|c|}
\hline $\begin{array}{c}\text { No. of } \\
\text { Patients }\end{array}$ & Gender & Age & Side & $\begin{array}{c}\text { No. of } \\
\text { Exposures }\end{array}$ & $\begin{array}{c}\text { No. of } \\
\text { Attempts }\end{array}$ & $\begin{array}{c}\text { NRS Score } \\
\text { Before }\end{array}$ & $\begin{array}{c}\text { NRS Score } \\
\text { After } \\
\end{array}$ & $\begin{array}{l}\text { \% Pain } \\
\text { Relief }\end{array}$ \\
\hline $1 \mathrm{R}^{1}$ & M & 45 & $\mathrm{R}$ & 9 & 1 & 8 & 1 & 88 \\
\hline $1 \mathrm{~L}^{2}$ & M & 45 & $\mathrm{~L}$ & 10 & 1 & 8 & 2 & 75 \\
\hline $2 \mathrm{R}$ & $\mathrm{F}$ & 62 & $\mathrm{R}$ & 8 & 1 & 9 & 1 & 89 \\
\hline $2 \mathrm{~L}$ & $\mathrm{~F}$ & 62 & $\mathrm{~L}$ & 6 & 1 & 8 & 1 & 88 \\
\hline $3 \mathrm{R}$ & $\mathrm{M}$ & 37 & $\mathrm{R}$ & 8 & 1 & 10 & 1 & 90 \\
\hline $3 \mathrm{~L}$ & $M$ & 37 & $\mathrm{~L}$ & 10 & 1 & 9 & 1 & 89 \\
\hline $4 \mathrm{R}$ & M & 41 & $\mathrm{R}$ & 6 & 1 & 7 & 0 & 100 \\
\hline $4 \mathrm{~L}$ & M & 41 & $\mathrm{~L}$ & 10 & 1 & 8 & 0 & 100 \\
\hline $5 \mathrm{R}$ & $\mathrm{F}$ & 50 & $\mathrm{R}$ & 12 & 1 & 9 & 2 & 78 \\
\hline $5 \mathrm{~L}$ & $\mathrm{~F}$ & 50 & $\mathrm{~L}$ & 11 & 1 & 9 & 2 & 80 \\
\hline $6 \mathrm{R}$ & $\mathrm{F}$ & 64 & $\mathrm{R}$ & 9 & 1 & 8 & 1 & 78 \\
\hline $6 \mathrm{~L}$ & $\mathrm{~F}$ & 64 & $\mathrm{~L}$ & 10 & 1 & 9 & 1 & 89 \\
\hline $7 \mathrm{R}$ & $\mathrm{M}$ & 58 & $\mathrm{R}$ & 8 & 1 & 10 & 2 & 80 \\
\hline $7 \mathrm{~L}$ & $\mathrm{M}$ & 58 & $\mathrm{~L}$ & 9 & 1 & 10 & 2 & 80 \\
\hline $8 \mathrm{R}$ & M & 35 & $\mathrm{R}$ & 6 & 1 & 9 & 0 & 100 \\
\hline $8 \mathrm{~L}$ & M & 35 & $\mathrm{~L}$ & 9 & 1 & 10 & 0 & 100 \\
\hline $9 \mathrm{R}$ & $\mathrm{F}$ & 43 & $\mathrm{R}$ & 12 & 2 & 7 & 1 & 86 \\
\hline $9 \mathrm{~L}$ & $\mathrm{~F}$ & 43 & $\mathrm{~L}$ & 9 & 1 & 8 & 0 & 100 \\
\hline $10 \mathrm{R}$ & $\mathrm{M}$ & 46 & $\mathrm{R}$ & 9 & 1 & 8 & 0 & 100 \\
\hline $10 \mathrm{~L}$ & $M$ & 46 & $\mathrm{~L}$ & 10 & 1 & 8 & 2 & 75 \\
\hline $11 \mathrm{R}$ & $\mathrm{F}$ & 52 & $\mathrm{R}$ & 9 & 1 & 9 & 2 & 78 \\
\hline $11 \mathrm{~L}$ & $\mathrm{~F}$ & 52 & $\mathrm{~L}$ & 9 & 1 & 9 & 2 & 78 \\
\hline $12 \mathrm{R}$ & $\mathrm{M}$ & 41 & $\mathrm{R}$ & 7 & 1 & 7 & 1 & 86 \\
\hline $12 \mathrm{~L}$ & $\mathrm{M}$ & 41 & $\mathrm{~L}$ & 6 & 1 & 7 & 1 & 86 \\
\hline $13 \mathrm{R}$ & $\mathrm{M}$ & 49 & $\mathrm{R}$ & 7 & 1 & 8 & 2 & 75 \\
\hline $13 \mathrm{~L}$ & $\mathrm{M}$ & 49 & $\mathrm{~L}$ & 8 & 1 & 7 & 1 & 78 \\
\hline $14 \mathrm{R}$ & $\mathrm{M}$ & 59 & $\mathrm{R}$ & 12 & 1 & 9 & 2 & 78 \\
\hline $14 \mathrm{~L}$ & $\mathrm{M}$ & 59 & $\mathrm{~L}$ & 11 & 1 & 8 & 2 & 75 \\
\hline $15 \mathrm{R}$ & $\mathrm{F}$ & 65 & $\mathrm{R}$ & 9 & 1 & 10 & 2 & 80 \\
\hline $15 \mathrm{~L}$ & $\mathrm{~F}$ & 65 & $\mathrm{~L}$ & 11 & 1 & 7 & 2 & 72 \\
\hline $16 \mathrm{R}$ & $\mathrm{F}$ & 34 & $\mathrm{R}$ & 8 & 1 & 9 & 1 & 89 \\
\hline $16 \mathrm{~L}$ & $\mathrm{~F}$ & 34 & $\mathrm{~L}$ & 6 & 1 & 8 & 1 & 88 \\
\hline 17 & $\mathrm{~F}$ & 56 & $\mathrm{~L}$ & 9 & 1 & 10 & 0 & 100 \\
\hline 18 & $\mathrm{M}$ & 40 & $\mathrm{R}$ & 11 & 1 & 8 & 2 & 75 \\
\hline 19 & $\mathrm{M}$ & 45 & $\mathrm{R}$ & 10 & 1 & 8 & 1 & 88 \\
\hline 20 & $\mathrm{M}$ & 52 & $\mathrm{R}$ & 11 & 1 & 8 & 1 & 88 \\
\hline 21 & $\mathrm{~F}$ & 56 & $\mathrm{R}$ & 10 & 1 & 9 & 1 & 89 \\
\hline 22 & $\mathrm{~F}$ & 58 & $\mathrm{~L}$ & 9 & 1 & 7 & 2 & 72 \\
\hline 23 & $\mathrm{M}$ & 44 & $\mathrm{~L}$ & 10 & 1 & 7 & 3 & 58 \\
\hline 24 & $\mathrm{M}$ & 39 & $\mathrm{R}$ & 7 & 1 & 8 & 1 & 88 \\
\hline 25 & $\mathrm{~F}$ & 50 & $\mathrm{~L}$ & 10 & 1 & 9 & 0 & 100 \\
\hline 26 & $\mathrm{M}$ & 54 & $\mathrm{~L}$ & 8 & 1 & 7 & 2 & 72 \\
\hline 27 & $\mathrm{M}$ & 59 & $\mathrm{R}$ & 9 & 1 & 10 & 3 & 70 \\
\hline
\end{tabular}


Table 1 (cont.). Demographic data and procedural characteristics.

\begin{tabular}{|c|c|c|c|c|c|c|c|c|}
\hline $\begin{array}{c}\text { No. of } \\
\text { Patients }\end{array}$ & Gender & Age & Side & $\begin{array}{c}\text { No. of } \\
\text { Exposures }\end{array}$ & $\begin{array}{c}\text { No. of } \\
\text { Attempts }\end{array}$ & $\begin{array}{l}\text { NRS Score } \\
\text { Before }\end{array}$ & $\begin{array}{c}\text { NRS Score } \\
\text { After }\end{array}$ & $\begin{array}{l}\text { \% Pain } \\
\text { Relief }\end{array}$ \\
\hline 28 & F & 45 & $\mathrm{R}$ & 12 & 1 & 10 & 2 & 80 \\
\hline 29 & M & 42 & $\mathrm{R}$ & 10 & 1 & 7 & 0 & 100 \\
\hline 30 & M & 60 & $\mathrm{~L}$ & 7 & 1 & 8 & 3 & 63 \\
\hline 31 & $\mathrm{~F}$ & 46 & $\mathrm{R}$ & 11 & 1 & 7 & 2 & 86 \\
\hline 32 & $\mathrm{~F}$ & 45 & $\mathrm{R}$ & 8 & 1 & 7 & 2 & 72 \\
\hline 33 & $\mathrm{M}$ & 37 & $\mathrm{~L}$ & 6 & 1 & 9 & 2 & 78 \\
\hline 34 & $M$ & 42 & $\mathrm{R}$ & 7 & 1 & 10 & 0 & 100 \\
\hline 35 & $\mathrm{~F}$ & 36 & $\mathrm{~L}$ & 12 & 1 & 8 & 1 & 88 \\
\hline 36 & $M$ & 59 & $\mathrm{R}$ & 10 & 1 & 10 & 3 & 70 \\
\hline 37 & $\mathrm{~F}$ & 30 & $\mathrm{R}$ & 6 & 1 & 8 & 2 & 75 \\
\hline 38 & $\mathrm{~F}$ & 62 & $\mathrm{~L}$ & 12 & 2 & 8 & 0 & 100 \\
\hline 39 & M & 40 & $\mathrm{R}$ & 9 & 1 & 9 & 2 & 78 \\
\hline 40 & M & 59 & $\mathrm{R}$ & 11 & 2 & 10 & 1 & 90 \\
\hline 41 & $\mathrm{~F}$ & 64 & $\mathrm{~L}$ & 10 & 1 & 9 & 1 & 89 \\
\hline 42 & $\mathrm{M}$ & 39 & $\mathrm{~L}$ & 6 & 1 & 9 & 0 & 100 \\
\hline 43 & $\mathrm{~F}$ & 28 & $\mathrm{~L}$ & 6 & 1 & 7 & 2 & 72 \\
\hline 44 & M & 36 & $\mathrm{R}$ & 7 & 1 & 8 & 2 & 86 \\
\hline 45 & $F$ & 44 & $\mathrm{R}$ & 8 & 1 & 9 & 1 & 89 \\
\hline 46 & $\mathrm{M}$ & 33 & $\mathrm{~L}$ & 9 & 1 & 7 & 2 & 72 \\
\hline 47 & $\mathrm{~F}$ & 27 & $\mathrm{~L}$ & 9 & 1 & 10 & 0 & 100 \\
\hline 48 & $\mathrm{M}$ & 63 & $\mathrm{~L}$ & 11 & 2 & 10 & 1 & 90 \\
\hline 49 & $\mathrm{~F}$ & 33 & $\mathrm{R}$ & 7 & 1 & 9 & 1 & 89 \\
\hline 50 & $\mathrm{~F}$ & 41 & $\mathrm{~L}$ & 6 & 1 & 8 & 0 & 100 \\
\hline 51 & $\mathrm{~F}$ & 39 & $\mathrm{~L}$ & 8 & 1 & 8 & 2 & 75 \\
\hline 52 & $M$ & 63 & $\mathrm{R}$ & 11 & 1 & 9 & 2 & 78 \\
\hline 53 & $\mathrm{M}$ & 32 & $\mathrm{R}$ & 9 & 1 & 10 & 1 & 90 \\
\hline 54 & $\mathrm{~F}$ & 65 & $\mathrm{R}$ & 12 & 2 & 10 & 1 & 90 \\
\hline 55 & $\mathrm{~F}$ & 40 & $\mathrm{~L}$ & 8 & 1 & 9 & 1 & 89 \\
\hline 56 & $M$ & 51 & $\mathrm{R}$ & 10 & 1 & 9 & 1 & 89 \\
\hline 57 & $M$ & 49 & $\mathrm{~L}$ & 10 & 1 & 8 & 1 & 88 \\
\hline
\end{tabular}

${ }^{1} 1$ R: Right SIJ of patient number one. ${ }^{2} 1 \mathrm{~L}$ : Left SIJ of patient number one.

obtained by applying few radiologic exposures. Also, when the needle is suspected to be in the joint by 2 3-degree oblique angulation of the $\mathrm{C}$-arm tube, we can confirm needle position before injecting the contrast material, which will make the correction of needle placement more difficult if it was misplaced. In this case series, we recorded the number of $x$-ray exposures, which was about $9 \pm 3$. There was not a significant difference between cases according to gender of the patients $(P=0.1)$ or side of the joint $(P=0.2)$. Successful intraarticular contrast spread was obtained in all SIJs.
Table 2. Mean values considering SIJ side.

\begin{tabular}{||l|c|c|c|}
\hline & Right & Left & P-Value \\
\hline No. of Cases (Joints) & $38(52.1 \%)$ & $35(47.9 \%)$ & - \\
\hline Mean Age & $47.47 \pm 10.18$ & $47.45 \pm 11.17$ & $P=0.9$ \\
\hline No. of $\geq 1$ Attempts & 3 & 2 & $P=0.4$ \\
\hline NRS Score Before & $8.68 \pm 1.04$ & $8.31 \pm 0.99$ & $P=0.1$ \\
\hline NRS Score After & $1.34 \pm 0.78$ & $1.22 \pm 0.91$ & $P=0.5$ \\
\hline Mean \% of Pain Relief & $85.13 \pm 8.46$ & $84.54 \pm 11.88$ & $P=0.8$ \\
\hline
\end{tabular}

${ }^{1}$ Total number of SIJs is considered as number of cases. 
Table 3. Mean values considering gender.

\begin{tabular}{|c|c|c|c|}
\hline & Female $^{1}$ & Male $^{2}$ & $P$-Value \\
\hline No. of Cases (Joints) ${ }^{3}$ & $33(45.2 \%)$ & $40(54.8 \%)$ & - \\
\hline Mean Age & $48.63 \pm 12.10$ & $46.50 \pm 9.20$ & $P=0.3$ \\
\hline No. of $\geq 1$ Attempts & 3 & 2 & $P=0.4$ \\
\hline NRS Score Before & $8.51 \pm 0.97$ & $8.50 \pm 1.08$ & $P=0.9$ \\
\hline NRS Score After & $1.21 \pm 0.73$ & $1.35 \pm 0.92$ & $P=0.4$ \\
\hline Mean \% of Pain Relief & $85.69 \pm 9.12$ & $84.15 \pm 11.03$ & $P=0.5$ \\
\hline
\end{tabular}

${ }^{1}$ Considering joint belonging to female patient. ${ }^{2}$ Considering joint belonging to male patient. ${ }^{3}$ Total number of SIJs is considered as number of cases.

\begin{tabular}{||l|l|l||}
\hline & R1 vs. L2 & M3 vs F4 \\
\hline$P$-Value for No. of Exposure & 0.2 & 0.1 \\
\hline
\end{tabular}

1) Right joint. 2) Left joint. 3) Considering joint belonging to female patient. 4) Considering joint belonging to male patient.

In 5 cases, the first needle placement was not correct and further replacements were required for entering the joint space; we detected needle malposition in 2 3-degree oblique views before injecting the contrast in those cases, and the needle was repositioned. There were no differences between gender $(P=0.4)$ and side of the joint $(P=0.4)$, considering the first successful attempt. The NRS pain scores after the procedure decreased in all patients more than $50 \%$, and all of the cases that had severe pain, with NRS score $\geq 7$, reported mild pain with NRS $\leq 3$ after the procedure, with no difference in NRS scores before and after the successful procedure regarding gender (Table 3 ) and side of SIJ (Table 2). The pain scores were similar to the results of classic methods of intraarticular interventions with successful contrast spread, and there were no remarkable differences regarding gender $(P=0.5)$ or side of the joint $(P=0.8)(12)$.

\section{Conclusion}

This observational study introduced a new, simple approach for SIJ intraarticular intervention. Further blinded clinical trials are needed to clarify the probable advantages of this method compared with conventional methods.

\section{References}

1. Hansen HC, McKenzie-Brown AM, Cohen SP, Swicegood JR, Colson JD, Manchikanti L. Sacroiliac joint interventions: A systematic review. Pain Physician 2007; 10:165-184.

2. Manchikanti L, Abdi S, Atluri S, Benyamin RM, Boswell MV, Buenaventura RM, Bryce DA, Burks PA, Caraway DL, Calodney AK, Cash KA, Christo PJ, Cohen SP, Colson J, Conn A, Cordner H, Coubarous S, Datta S, Deer TR, Diwan S, Falco FJ, Fellows B, Geffert S, Grider JS, Gupta S, Hameed $\mathrm{H}$, Hameed M, Hansen $H$, Helm S 2nd, Janata JW, Justiz R, Kaye AD, Lee M, Manchikanti KN, McManus CD, Onyewu O, Parr AT, Patel VB, Racz GB, Sehgal N, Sharma ML, Simopoulos TT, Singh V, Smith HS, Snook LT, Swicegood JR, Vallejo R, Ward SP, Wargo BW, Zhu J, Hirsch JA. An update of comprehensive evidence-based guidelines for interventional techniques in chronic spinal pain. Part II: Guidance and recommendations. Pain Physician 2013; 16:S49-S283.

3. Dussault RG, Kaplan PA, Anderson MW. Fluoroscopy-guided sacroiliac joint injections. Radiology 2000; 214:273-277.

4. Liliang PC, Liang CL, Lu K, Weng HC,
Syu FK. Modified fluoroscopy-guided sacroiliac joint injection: A technical report. Pain Med 2014; 15:1477-1480.

5. Rosenberg JM, Quint TJ, de Rosayro AM. Computerized tomographic localization of clinically-guided sacroiliac joint injections. Clin J Pain 2000; 16:18-21.

6. Centeno CJ. How to obtain an SI joint arthrogram $90 \%$ of the time in 30 seconds or less. Pain Physician 2006; 9:159.

7. Daitch J, Frey M, Snyder K. Modified sacroiliac joint injection technique. Pain Physician 2006; 9:367-368.

8. Forst SL, Wheeler MT, Fortin JD, Vilensky JA. The sacroiliac joint: Anatomy, physiology and clinical significance. Pain Physician 2006; 9:61-67.

9. Fortin J, Sehgal N. Sacroiliac joint intervention and arthrography with imaging correlation. In: Lennard TA (ed). Pain Procedures in Clinical Practice. Hanley \& Belfus, Philadelphia 2000, pp 265-273.

10. Slipman CW, Whyte WS 2nd, Chow DW, Chou L, Lenrow D, Ellen M. Sacroiliac joint syndrome. Pain Physician 2001; 4:143-152.

11. Vilensky JA, O'Connor BL, Fortin JD, Merkel GJ, Jimenez AM, Scofield BA,
Kleiner J B. Histologic analysis of neural elements in the human sacroiliac joint. Spine 1976; 27:1202-1207.

12. Kasliwal PJ, Kasliwal S. Fluoroscopyguided sacroiliac joint injection: Description of a modified technique. Pain Physician 2016; 19:E329-E338.

13. Jee H, Lee JH, Park KD, Ahn J, Park Y. Ultrasound-guided versus fluoroscopyguided sacroiliac joint intra-articular injections in the noninflammatory sacroiliac joint dysfunction: A prospective, randomized, single-blinded study. Arch Phys Med Rehabil 2014; 95:330-337.

14. Loomba D, Mahajan G. Sacroiliac joint pain. In: Smith HS (ed). Current Therapy in Pain. Elsevier Health Sciences, Philadelphia 2008, pp 354-363.

15. Vleeming A, Schuenke MD, Masi AT, Carreiro JE, Danneels L, Willard FH. The sacroiliac joint: An overview of its anatomy, function and potential clinical implications. J Anat 2012; 221:537-567.

16. Gupta S. Double needle technique: An alternative method for performing difficult sacroiliac joint injections. Pain Physician 2011; 14:281-284. 